\title{
Calculating Fission Product Inventories in Peach Bottom FTE-4 Fuel Rods Using the ORIGEN Code
}

\author{
W. Davis, Jr. \\ C. W. Kee \\ V.C.A. Vaughen \\ M. L. Tobias
}

\section{MASTER}




\section{Printed in the United States of America. Available from National Technical Information Service \\ U.S. Department of Commerce \\ 5285 Port Royal Road, Springfield, Virginia 22161 \\ Price: Printed Copy $\$ 3.50$; Microfiche $\$ 3.00$}

This report was prepared as an account of work sponsored by the United States Government. Neither the United States nor the Energy Research and Development Administration/United States Nuclear Regulatory Commission, nor any of their employees, nor any of their contractors, subcontractors, or their employees, makes any warranty, express or implied, or assumes any legal liability or responsibility for the accuracy, completeness or usefulness of any information, apparatus, product or process disclosed, or represents that its use would not infringe privately owned rights. 


\section{DISCLAIMER}

This report was prepared as an account of work sponsored by an agency of the United States Government. Neither the United States Government nor any agency Thereof, nor any of their employees, makes any warranty, express or implied, or assumes any legal liability or responsibility for the accuracy, completeness, or usefulness of any information, apparatus, product, or process disclosed, or represents that its use would not infringe privately owned rights. Reference herein to any specific commercial product, process, or service by trade name, trademark, manufacturer, or otherwise does not necessarily constitute or imply its endorsement, recommendation, or favoring by the United States Government or any agency thereof. The views and opinions of authors expressed herein do not necessarily state or reflect those of the United States Government or any agency thereof. 


\section{DISCLAIMER}

Portions of this document may be illegible in electronic image products. Images are produced from the best available original document. 
ORNL/TM-5691

Dist. Category UC-77

Contract No. W-7405-eng-26

CHEMICAL TECHNOLOGY DIVISION

\section{CALCULATING FISSION PRODUCT INVENTORIES IN PEACH BOTTOM FTE-4 FUEL RODS USING THE ORIGEN CODE}

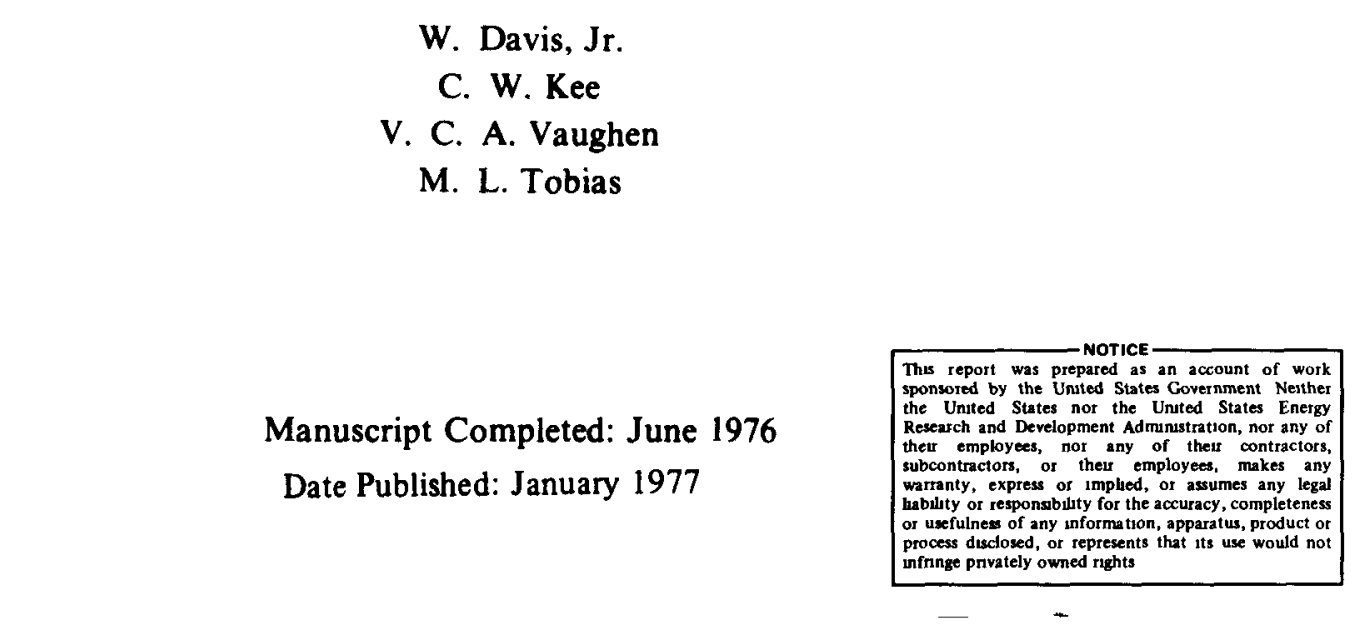

NOTICE This document contains information of a prelımınary nature

It is subject to revision or correction and therefore does not represent a

final report

Prepared by the

OAK RIDGE NATIONAL LABORATORY

OAK RIDGE, TENNESSEE 37830

operated by

UNION CARBIDE CORPORATION

for the

ENERGY RESEARCH AND DEVELOPMENT ADMINISTRATION 


\title{
CALCULATING FISSION PRODUCT INVENTORIES IN PEACH BOTTOM FTE-4 FUEL RODS USING THE ORIGEN CODE
}

\author{
W. Davis, Jr., C. W. Kee, V. C. A. Vaughen, and M. L. Tobias
}

\begin{abstract}
Nondestructive gamma-ray analyses (NDA) for fission products and mass-spectrometric analyses for five uranium isotopes in two samples of fuel removed from the Peach Bottom reactor have been compared with corresponding quantities calculated from reactor operating data using the ORIGEN code to form the basis for material balance calculations in head-end reprocessing steps. Satisfactory agreement between ORIGEN results and measured uranium isotopic distributions was found with the standard ORIGEN inputs.

Many fission products of interest, including ${ }^{89} \mathrm{Sr},{ }^{91} \mathrm{Y},{ }^{95} \mathrm{Zr},{ }^{95} \mathrm{Nb},{ }^{103} \mathrm{Ru},{ }^{106} \mathrm{Ru}$, ${ }^{127} \mathrm{Te}^{*},{ }^{129} \mathrm{Te}^{*},{ }^{131} \mathrm{I},{ }^{134} \mathrm{Cs}$, and ${ }^{144} \mathrm{Ce}$, have half-lives that are less than about 2 years. Comparisons of ORIGEN calculations and NDA values for ${ }^{95} \mathrm{Zr},{ }^{106} \mathrm{Ru},{ }^{125} \mathrm{Sb},{ }^{134} \mathrm{Cs}$, ${ }^{144} \mathrm{Ce}$, and ${ }^{154} \mathrm{Eu}$ demonstrated the need to include realistic reactor operating data, including shutdown times, in the ORIGEN input parameters.
\end{abstract}

\section{INTRODUCTION}

Quantities of activation products (such as ${ }^{14} \mathrm{C}$ ), actinides, and fission products formed in samples and fuel rods irradiated in the Peach Bottom reactor ${ }^{1}$ may be calculated by use of the ORIGEN $^{2,3}$ code and various parameters. Nuclear data libraries used in these calculations are frequently updated ${ }^{3,4}$ to improve the accuracies of calculated values; these may be used to provide cross checks for mass balances calculated from analytical data obtained from head-end reprocessing studies and from nondestructive gamma-ray scanning. ${ }^{5}$ Tobias $^{6}$ has reported on some calculations for driver fuel and on the sensitivity of calculated values to the variation of several of the input parameters.

The usual calculations performed with ORIGEN are based on broad averages such as effective full-power days (EFPD). This approximation to reality is adequate for calculating reactor core inventories for nuclides with relatively long half-lives. However, for specific small fuel samples and for many nuclides of interest ${ }^{5}\left[\left(\right.\right.$ e.g., ${ }^{89} \mathrm{Sr},{ }^{91} \mathrm{Y},{ }^{95} \mathrm{Zr},{ }^{95} \mathrm{Nb},{ }^{103} \mathrm{Ru},{ }^{106} \mathrm{Ru}$, ${ }^{127} \mathrm{Te}^{*}(109 \mathrm{~d}),{ }^{129} \mathrm{Te}(33.4 \mathrm{~d}),{ }^{131} \mathrm{I},{ }^{134} \mathrm{Cs}$, and $\left.\left.{ }^{144} \mathrm{Ce}\right)\right]$, inventories calculated on the basis of EFPD will be biased with respect to true inventories because radioactive decay in the time corresponding to the difference between true calendar days and EFPD is neglected. This bias can be eliminated by use of irradiation data, including actual irradiation times and power levels during operating intervals and shutdown-time intervals. Additional improvement may be obtained from more detailed knowledge of fluxes at the specific rod locations in the reactor core during the successive irradiation intervals. 
obtained from more detailed knowledge of fluxes at the specific rod locations in the reactor core during the successive irradiation intervals.

The ORIGEN code requires input data obtained from flux and temperature distributions in the Peach Bottom reactor, as well as the various nuclear libraries that pertain to a high-temperature gas-cooled reactor. The terms THERM, RES, FAST, RITH, RING, RIF, etc., as defined by Bell, ${ }^{2}$ are calculated from available information and are described in the next section.

\section{PREPARATION OF ORIGEN INPUT DATA}

Tobias $^{6}$ has made calculations of ORIGEN input parameters for fuel element E06-01 in the Peach Bottom reactor; these are summarized in Table 1 and in the following equations in terms of the four-group fluxes listed by Wallroth.'

From the definitions:

$$
\begin{aligned}
& \mathrm{X} \equiv \varphi_{4} * \mathrm{Q} / \mathrm{W}, \\
& \mathrm{Y} \equiv \varphi_{1} * \mathrm{P} / \mathrm{R},
\end{aligned}
$$

and

$$
Z \equiv\left(\varphi_{1}-Y\right)+\varphi_{2}+\varphi_{3}+\left(\varphi_{4}-X\right)
$$

we may obtain the input values of THERM, RES, and FAST for ORIGEN as follows:

$$
\text { THERM }=\sqrt{\pi / 4 * 293.16 / T},
$$

where

$$
\begin{aligned}
\mathrm{T} & =\text { sample }(\text { in reactor }) \text { temperature, }{ }^{\circ} \mathrm{K} ; \\
\mathrm{RES} & =\mathrm{Z} /(\mathrm{X} * \mathrm{U}) ; \\
\text { FAST } & =1.45 * \mathrm{Y} / \mathrm{X} .
\end{aligned}
$$

The lethargy interval, U, conforms to Bell's definition of RITH. The definitions of ORIGEN terms SIGF, SIGNG, RING, and RIF are also used in the Tobias calculations; terms $\sigma_{f i}$ and $\sigma_{\mathfrak{c},}$ are average cross sections for fission and capture, respectively, of the fissile nuclide $\left({ }^{232} \mathrm{U}\right.$, ${ }^{233} \mathrm{U}$, or $\left.{ }^{235} \mathrm{U}\right)$ in the flux band $\mathrm{i}(\mathrm{i}=1,2,3,4)$. However, cross sections of each of the nuclides ${ }^{232} \mathrm{U},{ }^{233} \mathrm{U}$, and ${ }^{235} \mathrm{U}$ were calculated for this study as follows:

$$
\begin{aligned}
\text { SIGF } & =\sigma_{f 4} * \text { THERM, } \\
\text { SIGNG } & =\sigma_{c 4} * \text { THERM. }
\end{aligned}
$$

Finally,

$$
\begin{aligned}
\mathrm{RING} & =\mathrm{U}^{*}\left[\sigma_{c 1}\left(\varphi_{1}-\mathrm{Y}\right)+\sigma_{c 2 \varphi_{2}}+\sigma_{c 3 \varphi_{3}}+\sigma_{c 4}\left(\varphi_{4}-\mathrm{X}\right)\right] / \mathrm{Z} \\
\mathrm{RIF} & =\mathrm{U}^{*}\left[\sigma_{f 1}\left(\varphi_{1}-\mathrm{Y}\right)+\sigma_{f 2} \varphi_{2}+\sigma_{f 3} \varphi_{3}+\sigma_{f 4}\left(\varphi_{4}-\mathrm{X}\right)\right] / \mathrm{Z}
\end{aligned}
$$

The four-group cross sections used were from Table 2 of ref. 6 .

The current study uses a modified definition of SIGF, SIGNG, RING, and RIF, which results in the same final reaction rate for use in the ORIGEN calculations; however, different 
Table 1. Fluxes, lethargy intervals, and other parameters pertaining to Peach Bottom fuel

\begin{tabular}{|c|c|c|c|}
\hline Flux & $\begin{array}{c}\text { Upper energy, } \\
\mathrm{E}_{\mathrm{u}} \\
(\mathrm{eV}) \\
\end{array}$ & $\begin{array}{c}\text { Lower energy, } \\
E_{1} \\
(\mathrm{eV})\end{array}$ & $\begin{array}{l}\text { Iethargy interval } \\
{\left[\Delta \mathrm{u}=\operatorname{In}\left(\mathrm{E}_{\mathrm{u}} / \mathrm{E}_{1}\right)\right]}\end{array}$ \\
\hline$\varphi_{1}$ & $14.96 \mathrm{E}+6$ & $8.65 E+4$ & $5.1530 \equiv R$ \\
\hline$\varphi_{2}$ & $8.65 E+4$ & $1.76 \mathrm{E}+1$ & $8.5000 \equiv S$ \\
\hline$\varphi_{3}$ & $1.76 \mathrm{E}+1$ & 2.38 & $2.0008 \equiv v$ \\
\hline$\varphi_{4}$ & 2.38 & $0.001^{a}$ & $7.7749 \equiv w$ \\
\hline \multicolumn{4}{|c|}{$\begin{array}{l}P \equiv \ln (14.96 \mathrm{E}+6 / 1.0 \mathrm{E}+6)=2.7054 \\
Q \equiv \ln (0.5 / 0.001)=6.2146 \\
U \equiv \ln (1.0 \mathrm{E}+6 / 0.5)=14.5087\end{array}$} \\
\hline
\end{tabular}


intermediate numbers apply. The modified definitions used in this study are given in Sect. 2.2.

At present, values for flux $\varphi_{4}$ are available for the individual rods at only a few times, as shown in Table 2. These have been used to provide fluxes for use in the ORIGEN code. For example, at the three real times of 356,845 , and 1142 days after July 15,1970 , the values of $\varphi_{4}$ for sample FTE-4-3-5-7 were $3.374 \times 10^{13}, 4.294 \times 10^{13}$, and $4.530 \times 10^{13}$, respectively. ${ }^{1}$ Multiplying each of these by the ratio $\ln (0.5 / 0.001) / \ln (2.38 / 0.001)$, which equals 0.79932 , gives the three different values for flux used in these ORIGEN calculations.

\subsection{Calculation of ORIGEN Input Values from Peach Bottom Parameters}

Information provided by Wallroth has been used in desk-calculator calculations of input parameters required by ORIGEN; for convenience, it has also been used as the basis of a computer program (Appendix A) that generates both cards and magnetic tape information required for ORIGEN. The code to utilize the Peach Bottom reactor information uses fluxes, as in hand calculations, to determine THERM, RES, and FAST, and to determine the fluxes as a function of time. For determining the fluxes as a function of time, it is necessary to know the absolute value of $\varphi_{4}$ during each time period of the irradiation, including shutdown times when $\varphi_{4}=0$. The time-averaged ratios of $\varphi_{1} / \varphi_{4}, \varphi_{2} / \varphi_{4}$, and $\varphi_{3} / \varphi_{4}$ are also needed for each time period. In addition to the flux and temperature information, the program requires the composition of the sample, appropriate titles, and a list of decay times for which calculations are to be made. The irradiation, shutdown, and decay times may be presented as days (or hundredths of a day) following some reference time, or simply as calendar dates. In either case, the ORIGEN printout includes a table listing the corresponding days used in the ORIGEN calculations.

\subsection{Reactor Dependence of the Code}

The code assumes the input flux spectrum and cross sections given in Tables 1 and 2 of ref. 6. The ORIGEN code defines the cross sections of the main components (Table 2 of ref. 6) using only one of the factors (THERM) and a zero for resonant and fast cross sections. The thermal cross section is defined as:

$$
\Sigma \sigma_{i} \varphi_{1} /(\text { THERM * Flux })
$$

ORIGEN immediately collapses the three-group cross sections using THERM, RES, and FAST as weighting factors. Thus, after collapsing the cross sections and multiplying by the flux, the ORIGEN code will obtain a reaction rate of $\Sigma \sigma \varphi$. The end result is the same as that obtained by Tobias. 
Table 2. Irradiation, power, and flux data for samples FTE-4-3-1-8 and FTE-4-3-5-7

\begin{tabular}{|c|c|c|c|c|c|c|c|c|}
\hline \multirow{3}{*}{$\begin{array}{l}\text { Trever } \\
\text { time } \\
\text { point }\end{array}$} & \multirow{3}{*}{$\begin{array}{l}\text { Real } \\
\text { time } b \\
\text { (days) }\end{array}$} & \multirow{3}{*}{$\begin{array}{l}\text { Average } \\
\text { reactor } \\
\text { power } \\
{[\mathrm{MW}(\mathrm{t})]}\end{array}$} & \multirow{3}{*}{$\begin{array}{l}\text { Real } \\
\text { exposure } \\
\text { time } \\
\text { (days) } \\
\end{array}$} & \multirow{3}{*}{$\begin{array}{l}\text { Effective } \\
\text { full-power } \\
\text { daysa } \\
\text { (EFPD) }\end{array}$} & \multirow{2}{*}{\multicolumn{4}{|c|}{ 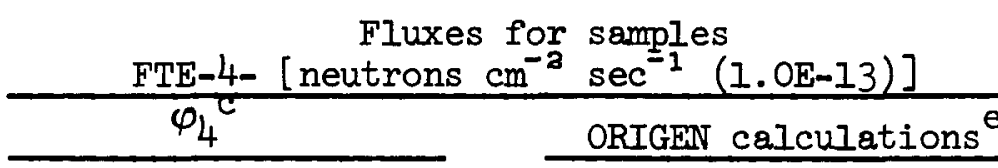 }} \\
\hline & & & & & & & & \\
\hline & & & & & $3-1-8$ & $3-5-7$ & $3-1-8$ & $3-5-7$ \\
\hline 7 & 356.1 & 94.2 & 56.4 & 46 & $\begin{array}{c}3.164 \\
(3.164)^{d}\end{array}$ & $\begin{array}{c}3.374 \\
(3.374)^{d}\end{array}$ & 2.53 & 2.70 \\
\hline 8 & 412.5 & 93.4 & 55.6 & 45 & $(3.164)^{\alpha}$ & $(3.374)^{d}$ & 2.53 & 2.70 \\
\hline 9 & 468.1 & 0. & 22.0 & 0 & 0 & 0 & 0 & 0 \\
\hline 10 & 490.1 & 103.2 & 47.0 & 42 & $(3.164)^{d}$ & $(3.374)^{d}$ & 2.53 & 2.70 \\
\hline 17 & 537.1 & 0. & 162.0 & 0 & 0 & 0 & 0 & 0 \\
\hline 12 & 699.1 & 91.0 & 145.9 & 115 & $(3.164)^{\mathrm{d}}$ & $(3.374)^{d}$ & 2.53 & 2.70 \\
\hline 13 & 845.0 & 0. & 46.0 & 0 & 4.038 & 4.294 & 0 & 0 \\
\hline 14 & 891.0 & 91.7 & 80.6 & 64 & $(4.038)^{d}$ & $(4.294)^{d}$ & 3.23 & 3.43 \\
\hline 15 & 971.6 & 103.2 & 51.5 & 46 & $(4.038)^{d}$ & $(4.294)^{d}$ & 3.23 & 3.43 \\
\hline 16 & 1023.1 & 0. & 20.0 & 0 & 0 & 0 & 0 & 0 \\
\hline 17 & 1043.1 & 106.4 & 98.8 & 91 & $(4.260)$ & $(4.530)$ & 3.41 & 3.62 \\
\hline 18 & 1141.9 & & & & 4.260 & 4.530 & & \\
\hline
\end{tabular}

bata from ref. 7 .

Since July 15, 1970.

dData from ref. 1 .

Assumed to be unchanged until a different value is given.

See text. 


\section{PRELIMINARY RESULTS AND COMPARISONS}

Preliminary results of ORIGEN calculations are shown for uranium isotopic compositions in Table 3 with the pertinent analytical data. Calculated and mass spectrometric values of uranium isotopic compositions appear to be in good agreement for samples FTE-4-3-1-8 and FTE-4-3-5-7. The word "good" is more qualitative than quantitative at present.

In like manner, fission-product activities are presented in Table 4. These fall into three groups: (1) sample FTE-4-3-5-7, for which there is good agreement between ORIGEN calculations and the results of the nondestructive (NDA) gamma-ray scanning for seven gamma-emitting isotopes; (2) sample FTE-4-3-1-8, for which there is a consistently low ratio NDA/ORIGEN; and (3) the two nuclides ${ }^{152} \mathrm{Eu}$ and ${ }^{155} \mathrm{Eu}$, for which there is no agreement between ORIGEN calculations and the gamma-ray scanning for either fuel sample.

The ratios of the values of NDA/ORIGEN approximate unity for ${ }^{95} \mathrm{Zr},{ }^{106} \mathrm{Ru},{ }^{125} \mathrm{Sb},{ }^{134} \mathrm{Cs}$, ${ }^{137} \mathrm{Cs},{ }^{144} \mathrm{Ce}$, and ${ }^{154} \mathrm{Eu}$. This is considered to be a satisfactorily close agreement. The actual average of these seven values for sample FTE-4-3-5-7 is 1.09; the standard deviation is 0.19 . The significantly lower values of the seven ratios, NDA/ORIGEN, for sample FTE-4-3-1-8 (average $=0.36$, standard deviation $=0.15$ ) are still under investigation by wet chemical techniques (the subject of a later report). The ${ }^{152} \mathrm{Eu}$ and ${ }^{155} \mathrm{Eu}$ discrepancies are explained by the low counting rates of these isotopes after a 2-year decay period.

Preliminary calculations were made to estimate the "residual nitrogen"a content of the fuel rods from ${ }^{14} \mathrm{C}$ analyses. The amount of $\mathrm{N}_{2}$ present during irradiation ("residual nitrogen") may be estimated by comparison of the ORIGEN results with the ${ }^{14} \mathrm{C}$ contents of the burner off-gases during the reprocessing studies (Table 5). The production of ${ }^{14} \mathrm{C}$ from ${ }^{14} \mathrm{~N}$ predominates over that from ${ }^{13} \mathrm{C}$. Based on the ratio of ${ }^{14} \mathrm{C}$ found experimentally to that produced from $1.0 \mathrm{~g}$ of $\mathrm{N}_{2}$ (per ORIGEN) we estimate that the "residual $\mathrm{N}_{2}$ " was $435 \mathrm{ppm}$ in rod 4-3-1-8, and $1640 \mathrm{ppm}$ in rod 4-3-5-7, based on total heavy-metal content. The ${ }^{14} \mathrm{C}$ values are valid only for fuel rods (i.e., matrix graphite and pyrolytic carbon). Block graphite was not analyzed in this study.

\section{DISCUSSION}

While some of the calculated results shown in Tables 3 and 4 suggest that the input data for two fuel samples from the Peach Bottom reactor yield relatively accurate ORIGEN results, at least two types of input data need further investigation, namely flux and the value of RES.

The fluxes used in ORIGEN (shown in Table 2) are based on only three sets of values for $\varphi_{1}, \varphi_{2}, \varphi_{3}$, and $\varphi_{4}$, although the power is seen to be different for each of the seven different nonzero power levels. A more detailed flux-time history obtained from reactor operating data appears likely to provide further improvement in ORIGEN calculations.

The second variable requiring additional investigation is RES. A series of calculations with the ORIGEN program, in which only RES was varied, showed that the quantities of ${ }^{95} \mathrm{Zr}$, ${ }^{106} \mathrm{Ru},{ }^{125} \mathrm{Sb}$, ${ }^{137} \mathrm{Cs}$, and ${ }^{144} \mathrm{Ce}$ (direct fission products) were not sensitive to the magnitude of

${ }^{a}$ It is likely that the fluidizing gas for the final LTI coating was $\mathrm{N}_{2}$, although it is not clear if definitive data for these verv early fuels can be retrieved at this time. ${ }^{7}$ 
Table 3. Uranium isotopic compositions and burnup

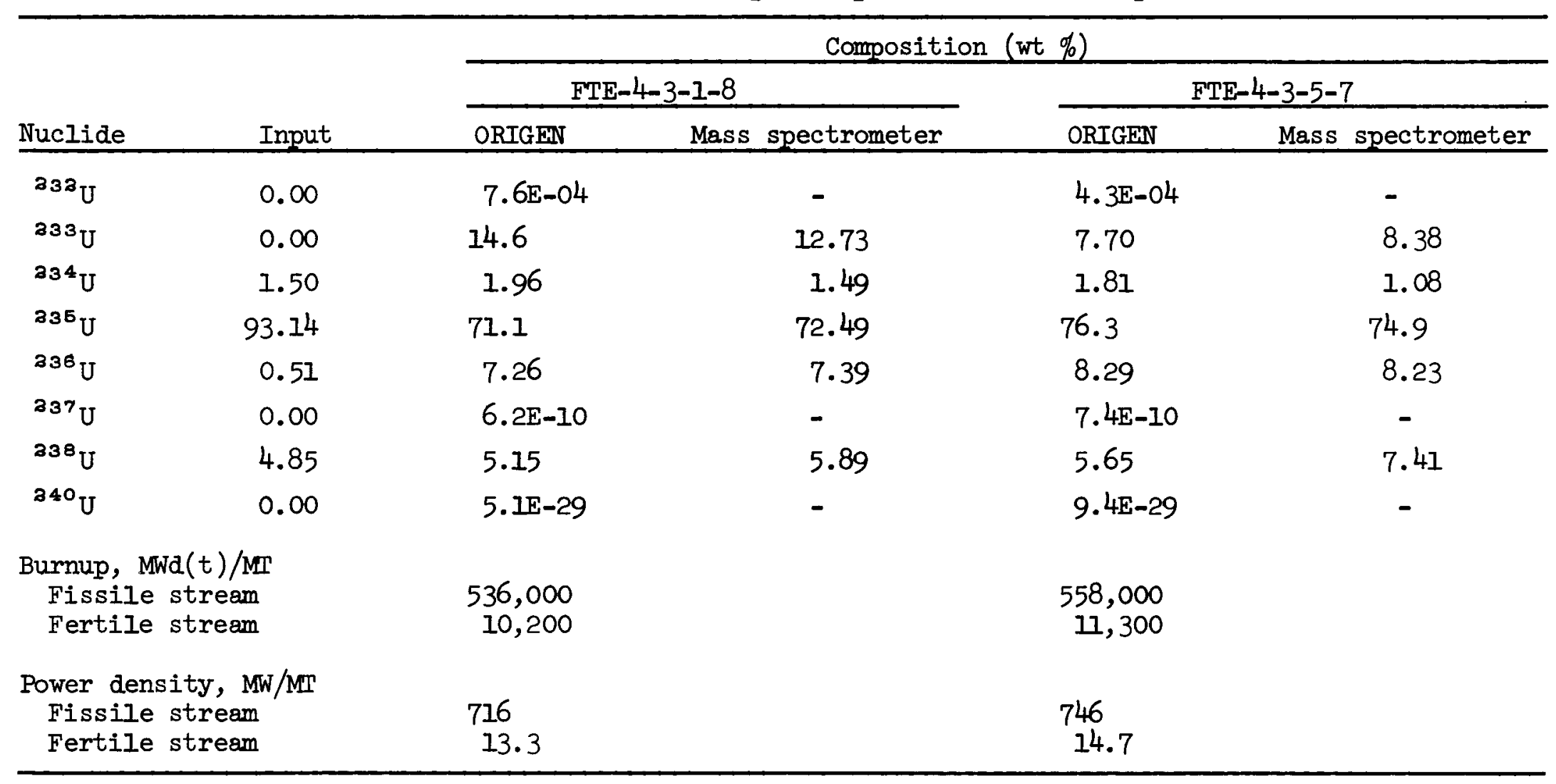


Table 4. Comparisons of fission-product activities, measured (NDA) and calculated (ORIGEN) ${ }^{2}$

\begin{tabular}{|c|c|c|c|c|c|c|}
\hline \multirow[b]{2}{*}{$\begin{array}{l}\text { Fission } \\
\text { product }\end{array}$} & \multicolumn{3}{|c|}{ FTE-4-3-1-8 } & \multicolumn{3}{|c|}{ FTE-4-3-5-7 } \\
\hline & ORIGEN & $\begin{array}{c}\text { Gamma scan } \\
(\mathrm{NDA})\end{array}$ & NDA/ORIGEN & ORIGEIN & $\begin{array}{c}\text { Gamma scan } \\
\text { (NDA) }\end{array}$ & NDA/ORIGEN \\
\hline${ }^{85} \mathrm{Kr}$ & $1.26 \mathrm{E}+11$ & & & $1.19 \mathrm{E}+11$ & & \\
\hline${ }^{90} \mathrm{Sr}$ & $1.01 E+12$ & & & $1.00 \mathrm{E}+12$ & & \\
\hline${ }^{95} \mathrm{Zr}$ & $8.08 \mathrm{E}+10$ & $3.17 E+10$ & 0.39 & $7.67 \mathrm{E}+10$ & $1.02 E+11$ & 1.33 \\
\hline${ }^{95} \mathrm{Nb}$ & $1.73 \mathrm{E}+11$ & & & $1.65 \mathrm{E}+11$ & & \\
\hline${ }^{106} \mathrm{Ru}$ & $3.89 \mathrm{E}+11$ & $1.13 \mathrm{E}+11$ & 0.29 & $3.97 \mathrm{E}+11$ & $5.00 \mathrm{E}+11$ & 1.27 \\
\hline${ }^{120} \mathrm{Ag}$ & $6.59 \mathrm{E}+09$ & & & $6.96 \mathrm{E}+09$ & & \\
\hline${ }^{135} \mathrm{Sb}$ & $3.67 \mathrm{E}+10$ & $1.78 \mathrm{E}+10$ & 0.49 & $3.33 E+10$ & $2.89 \mathrm{E}+10$ & 0.87 \\
\hline${ }^{134} \mathrm{Cs}$ & $5.43 \mathrm{E}+17$ & $1.04 \mathrm{E}+11$ & 0.19 & $5.81 E+11$ & $5.17 E+17$ & 0.88 \\
\hline${ }^{137} \mathrm{Cs}$ & $1.00 \mathrm{E}+12$ & $3.15 \mathrm{E}+11$ & 0.32 & $9.95 \mathrm{E}+11$ & $1.19 \mathrm{E}+12$ & 1.20 \\
\hline${ }^{144} \mathrm{Ce}$ & $4.47 \mathrm{E}+12$ & $1.14 \mathrm{E}+12$ & 0.26 & $4 \cdot 39 \mathrm{E}+12$ & $5.00 \mathrm{E}+12$ & 1.14 \\
\hline${ }^{163} \mathrm{Eu}$ & $1.03 \mathrm{E}+08$ & $4.44 \mathrm{E}+09$ & 43. & $9.83 E+07$ & $1.17 E+10$ & 113. \\
\hline${ }^{154} \mathrm{Eu}$ & $2.85 \mathrm{E}+10$ & $1.78 \mathrm{E}+10$ & 0.63 & $3.10 \mathrm{E}+10$ & $2.89 \mathrm{E}+10$ & 0.93 \\
\hline${ }^{155} \mathrm{Eu}$ & $6.64 \mathrm{E}+09$ & $1.11 E+11$ & 17. & $6.88 \mathrm{E}+\infty$ & $2.06 \mathrm{E}+11$ & 29.9 \\
\hline
\end{tabular}

activities are in distintegrations per minute for the whole sample. 
Table 5. Carbon-14 activities and calculated nitrogen contents for samples FTE-4-3-1-8 and FTE-4-3-5-7

\begin{tabular}{|c|c|c|}
\hline & \multicolumn{2}{|c|}{ FTE-4 sample } \\
\hline & $3-1-8$ & $3-5-7$ \\
\hline $\begin{array}{l}\text { Weight in sample, U+Th, } g \\
C, g\end{array}$ & $\begin{array}{l}5.74 \\
4.44\end{array}$ & $\begin{array}{l}2.93 \\
4.29\end{array}$ \\
\hline $\begin{array}{c}{ }^{14} \mathrm{C} \text { yield calculated from reaction } \\
{ }_{13} \mathrm{C}(n, \gamma) \text {, dpm/g } \mathrm{C} \\
{ }^{14} \mathrm{~N}(n, p) \text {, dpm/g } / \mathrm{N}\end{array}$ & $\begin{array}{l}1.083 \mathrm{E}+5 \\
1.245 \mathrm{E}+10\end{array}$ & $\begin{array}{l}1.146 \mathrm{E}+5 \\
1.316 \mathrm{E}+10\end{array}$ \\
\hline Measured ${ }^{14} \mathrm{C}$ activity, dpm/g C & $7.17 E+6$ & $1.49 \mathrm{E}+7$ \\
\hline 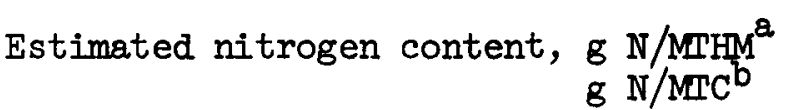 & $\begin{array}{l}435 \\
562\end{array}$ & $\begin{array}{l}1640 \\
1120\end{array}$ \\
\hline
\end{tabular}

MTrHM is metric tons of U+Th in the sample charged to the reactor. ${ }^{\mathrm{b}} \mathrm{MTC}$ is metric tons of carbon in the sample. 
RES. However, the quantities of ${ }^{134} \mathrm{Cs}$ and ${ }^{154} \mathrm{Eu}$ (activation products) are very sensitive to the value of RES. Further improvements in methods to calculate RES should yield improved estimates for the activation products.

\section{REFERENCES}

1. C. F. Wallroth, "FTE-4 and FTE-15 Fuel Rod Transfer to ORNL," letter to V. C. A. Vaughen, General Atomic Company File FTEA/202/CFW/75 (May 9, 1975).

2. M. J. Bell, ORIGEN - The ORNL Isotope Generation and Depletion Code, ORNL-4628 (May 1973).

3. ORIGEN - Isotope Generation and Depletion Code - Matrix Exponential Method, RSIC Computer Code Collection, CCC-217 (April 26, 1975).

4. C. W. Kee, A Revised Light Element Library for the ORIGEN Code, ORNL/TM-4896 (May 1975).

5. V. C. A. Vaughen F. F. Dyer, and K. H. Valentine, Determination of Fission Product Inventories in FTE-4 Fuel Rods by Gamma Scanning, GCR: 75-37 (December 1975).

6. M. Tobias, Estimates of Fission-Product Inventories in Fuel Element E06-01 of the Peach Bottom Core 2: Results, Comparisons, and Sensitivity Study, ORNL/TM-4705 (October 1974).

7. C. F. Wallroth, J. R. Holzgrath, D. D. Jensen, and L.R. Zumwalt, Post-irradiation Examination and Evaluation of Peach Bottom Fuel Test Elements FTE-4, General Atomics Co., GA-A13452 (to be published). 


\section{APPENDIX A. COMPUTER CALCULATION OF ORIGEN INPUT DATA FROM PEACH BOTTOM PARAMETERS}

The code to convert Peach Bottom reactor parameters to ORIGEN input data has been written in two versions. One version is for time-sharing use (PDP-10 version); it prompts the user for information. The time-sharing version allows free format input with consecutive input numbers separated by commas. The other version is for batch processing with card input (IBM 360 version); it assumes a standard order for the information. The batch version uses the formats listed below. The order in which the information is requested (or read) is the same for either version.

A. Reads: 10

Format: 15

IO is the unit number to be used for output of the ORIGEN deck. For the IBM 360, this should correspond to a DD card referencing the card punch or a disc file. For the PDP-10 at ORNL, a value of 1 to 4 or 10 to 29 results in output to a file FORnn.DAT where nn is the two digit representation of 10 .

B. Reads: TEMP

Format: $\quad F 10.0$

TEMP - Temperature in ${ }^{\circ} \mathrm{C}$

C. Reads: PHI1, PHI2, PHI3, PHI4

Format: $4 \mathrm{~F} 10.0$

These are the time averaged values of $\varphi_{1}, \varphi_{2}, \varphi_{3}$, and $\varphi_{4}$, respectively. Since only the ratios are important, common factors (such as $10^{13}$ ) may be omitted.

D. Reads: ISTRT, ITYPE

Format: $\quad 110,15$

ISTRT is the time at which irradiation starts.

ITYPE describes the format of ISTRT and all other times.

If ITYPE $=1$, all times are input as calendar dates. The first two digits from a six-digit time or the first four digits from an eight-digit time are interpreted as being the year. The next two digits are the month and the last two digits are the day of the month. The algorithm for determining the number of days between two dates considers leap years. As an added refinement, the algorithm considers century years as being leap years only when divisible by 400 if four-digit years are used. It is important that all dates have the same number of digits for the year (i.e., either 2 or 4 ) for any given case.

If ITYPE $=2$, all times are assumed to be given in hundredths of a day. If ITYPE $=3$, all times are assumed to be in days.

E. Reads: IIRR(I), FLX(I)

Format: 110, F10.0 
IIRR(I) is the end of the time period in which the flux $\varphi_{4}$ has the value FLX(I). Successive times are input until a nonpositive time occurs. If desired, any common factor of the flux values (e.g., $10^{13}$ ) can be listed as the flux corresponding to the time, which is nonpositive, since all previous values of the flux are multiplied by this number (if it is greater than one). All the times must be of the form referred to by ITYPE.

F. Reads: $\operatorname{IDEC}(\mathrm{J})$

Format: $\quad 110$

$\operatorname{IDEC}(\mathrm{J})$ is the time $(\mathrm{J})$ to be listed in the ORIGEN output as a decay time after reactor discharge. Times are read until a nonpositive value occurs. All must be defined as referenced by ITYPE.

G. Reads: CASE

Format: $10 \mathrm{~A} 4$

CASE is a 40-character case name used in constructing titles for ORIGEN output. The titles are constructed by adding "IRRADIATION TIMES" or "DECAY TIMES" as appropriate.

H. Reads: BASIS

Format: $\quad 10 \mathrm{~A} 4$

BASIS is a 40-character subtitle which appears in the ORIGEN output after the word "BASIS." BASIS and CASE are usually identified with a set of concentrations rather than with an irradition history.

I. Reads: NO, MASS, GATOM

Format: 12, 13, F10.3

Cards (or lines) of this type are read until a card (or line) with NO $=0$ is encountered. These values are the input composition. NO is the atomic number; MASS is the atomic mass; and GATOM is the charge in gram-atoms. The code distinguishes between materials of construction and actinides by examining the atomic number. If the material is a material of construction (i.e., NO $<85$ ), a naturally occurring element can be indicated by making MASS $=0$.

J. Reads: MORE

Format: 15

(MORE corresponds to NGO in the ORIGEN manual). There are two possible valid choices for MORE. If MORE is zero the code assumes that everything about the next case may be different and the next input is of type A. If MORE is negative the next case will have different titles and charge composition only. The next input is of type $G$ and inputs of type $A$ through $F$ are assumed to be the same. Positive values for MORE are not allowed. If a positive value is input by mistake, the code will behave as if MORE is negative, but the next case (if there is one) will not be run successfully by ORIGEN.

There are two normal ways for the program to stop. When 10 is read (type A) the program checks for an end-of-file indication. When input of type $C$ is read the program stops 
if $\mathrm{PHII}=0$.

Running the ORIGEN Deck

The output deck is a complete set of ORIGEN input. It can be run at ORNL with the following control cards:

Job card

Class card $(\mathrm{L}=20$, suggested)

/*ROUTE PRINT LOCAL (for PDP-10 submission)

// EXEC ORIGEN

//GO.FT05F001 DD *

Deck of ORIGEN input

$1^{*}$

11

If no materials of construction are needed, that part of the data library can be omitted by including the card //GO.FT25F001 DD DUMMY

just before the DD card for unit 5. If, during any execution of this program, the last value of MORE is zero, the deck may be followed by any other complete ORIGEN deck. As many decks as desired may be stacked in this way. 


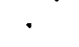


ORNL/TM-5691

Dist. Category UC-77

\section{INTERNAL DISTRIBUTION}

1. J. W. Allen

2. J. L. Anderson

3. B. J. Baxter

4. R. E. Blanco

5. J. 0. Blameke

6. W. D. Bond

7. J. Botts

8. R. E. Brooksbank

9. K. B. Brown

10. R. A. Bradley

11. W. D. Burch

12. C. Carney

13. J. Carter

14. W. L. Carter

15. C. F. Coleman

16. J. H. Coobs

17. J. H. Cooper

18. L. T. Corbin

19-27. W. Davis, Jr.

28. F. E. Dearing

29. F. F. Dyer

30. D. E. Fergus on

31. C. I. Fitzgerald

32. R. W. Glass

33. J. H. Goode

34. F. E. Harrington

35. C. C. Haws

36. J. R. Hightower

37. N. Holder

38. J. Holzgrath

39. F. J. Homan

40-47. P. R. Kasten

48-49. C. W. Kee

50. R. K. Kibbe

51. E. M. King

52. W. J. Lackey

53. W. Laing

54. C. E. Lamb
55. R. E. Leuze

56. K. H. Lin

57. T. B. Lindemer

58-59. E. L. Long

60-61. A. L. Lotts

62. A. P. Malinauskas

63. L. E. McNeese

64. R. P. Morisette

65. E. Newman

66. K. J. Notz

67. W. H. Pechin

68. R. H. Rainey

69. A. P. Roeh

70. A. D. Ryon

71. C. D. Scott

72. J. W. Snider

73. R. G. Stacy

74. T. N. Tiegs

75-76. M. L. Tobias

77. D. B. Trauger

78. W. E. Unger

79-88. V. C. A. Vaughen

89. K. H. Valentine

90. B. L. Vondra

91-92. C. F. Wallroth

93-94. R. P. Wichner

95. R. G. Wymer

96. R. D. Zinmerman

97. W. K. Davis (Consultant)

98. C. H. Ice (Consultant)

99. E. J. Gaden, Jr. (Consultant)

100. R. B. Richards (Consultant)

101-102. Central Research Library

103. Document Reference Section

104-105. Laboratory Records

106. Laboratory Records-RC

107. ORNL Patent Office 
108. Research and Technical Support Division, ERDA, ORO

109. Director, Reactor Division, ERDA, ORO

110-111. Director, Reactor Development and Demonstration, ERDA, Washington, DC 20545

112-113. Director, Division of Nuclear Fuel Cycle and Production, ERDA, Washington, DC 20545

114-289. Given distribution as shown in TID-4500 under Gas-Cooled Reactor Technology category, UC-77 (25 copies - NTIS) 